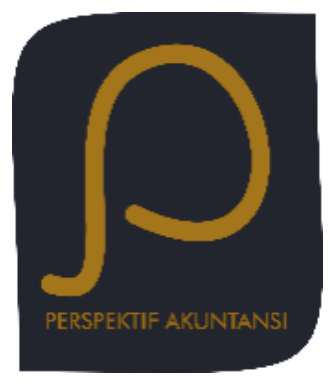

Perspektif Akuntansi

Volume 4 Nomor 3 (Oktober 2021), hal. 217-238

ISSN: 2623-0194 (Print), 2623-0186 (Online)

Copyright(C The Authors(s). All Rights Reserved

Center for Accounting Development and Research (CARD)

Fakultas Ekonomika dan Bisnis,

Universitas Kristen Satya Wacana

DOI: https://doi.org/10.24246/persi.vXiX.p217-238

http://ejournal.uksw.edu/persi

\title{
Hubungan Sistem Pengendalian Mutu Kantor Akuntan Publik dengan Etika Profesi dan Skeptisme Profesional Auditor
}

\author{
Cici Girik Allo \\ Yefta Andi Kus Noegroho ${ }^{1}$ \\ Universitas Kristen Satya Wacana
}

Received

10/05/2021

Revised

06/06/2021

Accepted

12/06/2021

\begin{abstract}
This study aims to examine the relationship between KAP Quality Control System with professional ethics and professional skepticism of auditor in carrying out the profession as a professional accountant. We used correlation as our research method. The population of the study was the auditors of KAP in Indonesia. We gained 96 respondents as the samples for this study. The data collecting technique uses primary data in the form of a questionnaire distributed online. The results of this study indicated that the Public Accountant Firm's Quality Control System has a positive relationship with professional ethics and professional skepticism of the auditors. The implementation of the Quality Control System in KAP becomes more effective in controlling quality service results, understanding professional ethics and high skepticism in carrying out professional duties for the auditors. The benefit of this research is to be a reference for public accounting firms in improving performance and creating a good work environment for the auditors.
\end{abstract}

Keywords: KAP Quality Control System, Professional Ethics and Professional Skepticism

${ }^{1}$ Yefta.Kusnugroho@uksw.edu 


\begin{abstract}
Abstrak. Penelitian ini bertujuan untuk menguji hubungan antara Sistem Pengendalian Mutu KAP dengan etika profesi dan skeptisisme profesional auditor dalam menjalankan profesi sebagai akuntan profesional. Kami menggunakan korelasi sebagai metode penelitian kami. Populasi penelitian ini adalah auditor KAP di Indonesia. Kami memperoleh 96 responden sebagai sampel untuk penelitian ini. Teknik pengumpulan data menggunakan data primer berupa kuesioner yang disebarkan secara online. Hasil penelitian ini menunjukkan bahwa Sistem Pengendalian Mutu Kantor Akuntan Publik memiliki hubungan positif dengan etika profesi dan skeptisme profesional auditor. Penerapan Sistem Pengendalian Mutu di KAP menjadi lebih efektif dalam mengendalikan kualitas hasil pelayanan, memahami etika profesi dan skeptisisme yang tinggi dalam melaksanakan tugas profesional bagi auditor. Manfaat dari penelitian ini adalah menjadi acuan bagi Kantor Akuntan Publik dalam meningkatkan kinerja dan menciptakan lingkungan kerja yang baik bagi auditor.
\end{abstract}

Kata kunci: Sistem Pengendalian Mutu KAP, Etika Profesi dan Skeptisisme Profesi

\title{
Pendahuluan
}

Setiap profesi dituntut untuk bekerja secara profesional. Seseorang harus memiliki etika dan harus mematuhi aturan-aturan dalam menjalankan sebuah profesi (Juhara, 2017). Masyarakat dapat menilai sejauh mana seorang auditor bekerja sesuai dengan standar etika yang telah ditetapkan oleh profesinya (Maulita, 2015). Auditor dituntut untuk lebih profesional dan beretika dalam melaksanakan tugas-tugas profesinya.

Di tengah tuntutan tuntutan profesionalitas dan etika auditor, ternyata masih banyak terjadi masalah yang dapat menurunkan kepercayaan masyarakat terhadap profesi auditor. Bukti masalah yang terjadi terkait profesi auditor adalah adanya Kantor Akuntan Publik (KAP) lokal yang berafiliasi dengan KAP global Ernst \& Young setuju untuk membayar denda sebesar US\$ 1 juta atau sekitar Rp 13 miliar setelah regulator audit AS menemukan penyimpangan pada hasil audit KAP itu pada sebuah perusahaan telekomunikasi di Indonesia (Malik, 2017). Kasus lain adalah sebuah KAP di Brasil yang berafiliasi dengan Deloitte \& Touche LLP juga didenda sebesar US\$ 8 juta karena mencoba menutup-nutupi audit palsu (Malik, 2017). Profesi auditor menjadi sorotan pembuat kebijakan dan sebagian masyarakat karena kasus menipulasi yang sering terjadi. Auditor harusnya bertanggung jawab untuk menjamin kualitas atau keandalan laporan keuangan yang diaudit sebagai pihak independen (Maulita, 2015), namun pada kenyataannya masih ada auditor yang turut dalam melakukan tindakan yang mengandung unsur kecurangan.

Salah satu upaya yang dapat dilakukan untuk menjaga dan meningkatkan kualitas audit adalah dengan menerapkan sistem pengendalian mutu KAP. Sistem pengendalian mutu dalam KAP berfungsi memastikan suatu output telah mencapai 
goals dan spesifikasi yang sebelumnya telah ditetapkan sehingga diperlukan penerapan sistem pengendalian mutu (quality control) yang baik dan dapat diwujudkan dengan penggunaan pedoman atau standar yang telah ditetapkan (Darmawati \& Puspitasari, 2018). Sistem pengendalian mutu merupakan acuan bagi KAP dalam melaksanakan pengendalian atas kualitas jasa yang dihasilkan oleh KAP.

Faktor lingkungan memiliki pengaruh untuk memastikan para auditor bekerja sesuai batasan nilai profesional dan etika demi mewujudkan hasil pekerjaan yang baik. Jika seorang auditor berada di lingkungan yang baik maka seorang auditor akan memiliki perilaku yang baik juga, sehingga kualitas auditor akan mendapatkan kepercayaan penuh dari masyarakat. Sebaliknya, jika berada di lingkungan yang buruk maka seorang auditor akan berperilaku buruk sehingga berdampak terhadap kualitas kinerja para auditor dan turunnya kepercayaan masyarakat terhadap para auditor. Sari \& Ratnadi (2018) mengatakan bahwa lingkungan menjadi salah satu faktor yang dapat mempengaruhi seorang auditor dalam memiliki sikap yang skeptis. Rustiana (2016) mengatakan bahwa seorang auditor pada tingkat skeptisme profesional yang tinggi akan mencari informasi lebih banyak dibandingkan auditor yang memiliki skeptisme profesional yang rendah. Semakin tinggi tingkat skeptis cenderung akan mempengaruhi auditor dalam pengambilan keputusan berdasarkan fakta yang ditemukan (Wirakusuma \& Sari, 2018).

Sistem pengendalian mutu KAP masih berada dalam tahap proses penerapan. Pradana \& Meiden (2016) mengatakan bahwa para auditor di Kantor Akuntan Publik masih berada dalam proses penyesuaian untuk mengimplementasikan sistem pengendalian mutu berdasarkan Standar Pengendalian Mutu Nomor 1 (SPM 1) secara utuh dan menyeluruh. Kemudian Darmawati \& Puspitasari (2018) mengatakan bahwa penerapan sistem pengendalian mutu berpengaruh terhadap kemampuan auditor dalam mendeteksi kecurangan. Di lain sisi, keberadaan etika profesi dan skeptisme profesional auditor terus mengalami perkembangan. Herman (2011) mengatakan bahwa etika profesi akuntan publik memiliki pengaruh yang sangat signifikan dalam peningkatan kinerja seorang auditor yang profesional. Kemudian, skeptisme profesional berpengaruh positif pada pendeteksian kecurangan dan juga menunjukkan adanya pengaruh positif antara etika dan pendeteksian kecurangan Wirakusuma \& Sari (2018). Keterkaitan antara faktor lingkungan dengan pembentukan etika dan skeptisme profesional auditor menjadi fokus persoalan yang perlu dicari keterkaitannya dalam mengembangkan lingkungan kerja yang baik dan profesional dalam lingkup kerja auditor.

Tujuan penelitian ini adalah menguji hubungan sistem pengendalian mutu KAP dengan etika profesi dan skeptisisme profesional auditor dalam menjalankan profesi sebagai akuntan profesional. Perbedaan penelitian ini dengan penelitian sejenis yang lain adalah dalam hal menghubungkan faktor organisatoris dengan perilaku auditor. Manfaat penelitian yang dapat diperoleh adalah para pihak yang mengelola dan menjalankan kegiatan KAP dapat memperoleh bukti pentingnya faktor lingkungan dalam upaya membentuk nilai dan kinerja auditor. Fokus pengelolaan KAP hendaknya tidak hanya terfokus pada individu auditor tetapi juga pada pembentukan 
lingkungan yang kondusif dalam upaya mewujudkan kinerja auditor yang profesional dan beretika. Sistematika penelitian ini disusun diawali dengan latar belakang masalah dan masalah penelitian, tujuan dan manfaat. Kemudian dilanjutkan dengan telaah teoritis dan pengembangan hipotesis serta gambaran metode penelitian yang digunakan. Akhirnya, kajian ini ditutup dengan hasil penelitian dan simpulan.

\section{Telaah Pustaka}

\section{Pengaruh Lingkungan terhadap Perilaku Individu}

Basuki (2008) menyatakan bahwa tingkah laku dari seorang individu bukan hanya sekedar refleks otomatis dan stimulus tetapi akibat dari reaksi yang ditimbulkan sebagai hasil dari interaksi antara lingkungan dan individu tersebut (Laila, 2015). Bandura (1986) mendefinisikan kognitif sebagai sebuah proses mental yang mungkin atau tidak direfleksikan dalam perubahan perilaku yang segera. Perubahan perilaku individu tergantung pada faktor lingkungan, orang dan perilaku. Teori kognitif sosial merupakan perilaku yang tercipta pada diri seseorang ketika seseorang mengamati dan meniru perilaku orang lain atau memperhatikan kejadian yang terjadi di lingkungan sekitarnya. Teori ini menyatakan bahwa seseorang dalam berperilaku dipengaruhi oleh lingkungan sekitarnya bagaimana mereka melihat dan merespon cara orang atau sekelompok dalam berperilaku. Bandura mengartikan teori kognitif sosial merupakan observasi dalam sebuah proses kognitif yang melibatkan pemikiran manusia seperti pemikiran, bahasa, regulasi diri perilaku dan moralitas (Laila, 2015).

\section{Sistem Pengendalian Mutu}

Standar Pengendalian Mutu (SPM) merupakan standar pokok dalam meningkatkan kepercayaan pengguna atas jasa yang disediakan oleh Kantor Akuntan Publik (Nanda, 2019). Rincian SPM 1 (2013), menyebutkan bahwa sistem pengendalian mutu KAP terdiri dari 7 (tujuh) elemen yaitu: (1) Tanggung jawab kepemimpinan KAP atas mutu, (2) Ketentuan etika profesi yang berlaku, (3) Penerimaan dan keberlanjutan hubungan dengan klien dan perikatan tertentu, (4) Sumber daya manusia, (5) Pelaksanaan perikatan, (6) Pemantauan dan (7) Dokumentasi.

Kepatuhan terhadap standar audit dan standar profesional akuntan publik khususnya dalam penerapan sistem pengendalian mutu merupakan salah satu unsur dalam menilai kualitas audit. Berdasarkan ketentuan SPM 1 (2013), sistem pengendalian mutu mengatur tanggung jawab KAP terhadap sistem pengendalian mutu dalam melaksanakan perikatan asurans (review, audit, dan perikatan asurans lainnya) dan perikatan selain asurans. Atas dasar tersebut, sistem pengendalian mutu KAP juga menurut standar audit dan standar profesional akuntan publik, penerapan sistem pengendalian mutu yang menjelaskan unsur sistem pengendalian mutu wajib diterapkan oleh KAP, serta hal yang terkait dengan implementasiannya secara efektif (Permana \& Setyawan, 2018). Sistem pengendalian mutu dapat memberikan penilaian yang tinggi terhadap KAP karena penerapan sistem pengendalian mutu dapat meningkatkan kepercayaan masyarakat terhadap pekerjaan suatu KAP. 
Dengan demikian sistem pengendalian mutu pada suatu organisasi auditor secara individu akan bervariasi dalam sifat dan lingkupnya (Nurrohmah, 2016).

\section{Etika Profesi Akuntan Publik}

Etika Profesi Akuntan Publik adalah aturan etika yang harus diterapkan oleh anggota Institut Akuntan Publik Indonesia atau IAPI (sebelumnya Ikatan Akuntan Indonesia Kompartemen Akuntan Publik atau IAIKAP) dan staf profesional (baik yang anggota IAPI maupun yang bukan anggota IAPI) yang bekerja pada satu Kantor Akuntan Publik (KAP). Masyarakat yang menggunakan jasa profesi akuntan publik pada dasarnya dilindungi oleh kode etik yang didalamnya terdapat muatan-muatan etika. Keraf (1998) menyatakan terdapat dua sasaran pokok dalam dua kode etik ini yaitu pertama, kode etik digunakan untuk melindungi kepentingan masyarakat dari kerugian yang diakibatkan oleh kelalaian baik secara disengaja maupun tidak. Kedua, kode etik memiliki tujuan untuk melindungi keseluruhan profesi dari tindakan atau perilaku buruk orang tertentu yang mengaku dirinya professional (Damawati \& Wahyuningsih, 2016).

Interpretasi aturan etika merupakan interpretasi yang dikeluarkan oleh badan yang dibentuk oleh profesi setelah memperhatikan tanggapan dari anggota dan pihakpihak berkepentingan lainnya, sebagai panduan dalam penerapan aturan etika tanpa dimaksudkan untuk membatasi lingkup dan penerapannya (Juhara, 2017). Prinsip etika profesi yang merupakan landasan perilaku etika profesional, terdiri atas delapan prinsip yaitu: (1) tanggung jawab profesi; (2) kepentingan umum (publik); (3) integritas; (4) objektivitas; (5) kompetensi dan kehati-hatian professional; (6) kerahasiaan; (7) perilaku profesional; dan (8) standar teknis.

\section{Skeptisisme Profesional Akuntan Publik}

Menurut International Federation of Accountants (IFAC) skeptisme berarti seorang auditor memiliki cara berpikir dan terus bertanya mengenai keabsahan dari bukti audit yang didapatkan dan memiliki kewaspadaan terhadap bukti yang kontradiktif dan jawaban atas pertanyaan serta informasi yang diajukan kepada pihak manajemen dan mereka yang berwenang sebagai pengelola, hal itu dapat dilakukan oleh seorang auditor dalam membuat sebuah penilaian yang kritis (Ningsih \& Nadirsyah, 2017). Skeptisme profesional adalah kewajiban para auditor dalam menggunakan dan mempertahankan sikap skeptis selama melakukan penugasan terkhusus dalam kewaspadaan terjadinya kecurangan (Ningsih \& Nadirsyah, 2017).

Auditor menerapkan sikap skeptisme profesional pada saat mengajukan pertanyaan dan menjalankan prosedur audit, dengan tidak cepat puas dengan bukti audit yang kurang persuasif yang hanya didasarkan pada kepercayaan bahwa manajemen dan pihak terkait bersikap jujur dan mempunyai integritas (Butar, 2017). Adanya sikap skeptisme auditor maka auditor dapat lebih teliti dalam mengevaluasi bukti audit sehingga mampu menemukan pelanggaran-pelanggaran yang ada pada laporan keuangan klien. Adanya evaluasi bukti audit secara terus-menerus maka akan menghasilkan laporan audit yang berkualitas (Mulyani \& Munthe, 2018). 


\section{Hubungan Sistem Pengendalian Mutu dengan Etika Profesi Akuntan Publik}

Dalam menjalankan profesi sebagai seorang auditor harus mematuhi dan memahami nilai-nilai etika dan mereka tidak boleh mengambil keuntungan dengan mengedepankan kepentingan pribadi (Primaraharjo \& Handoko, 2011). Setiap individu yang memberikan jasa profesional yang meliputi jasa assurance dan jasa selain assurance dalam Kantor Akuntan Publik (KAP) wajib untuk menerapkan prinsip dasar dan aturan etika yang telah ditetapkan seperti yang tercantum dalam standar profesi dan kode etik profesi (Juhara, 2017). SPM No.1 Tahun 2013 menjelaskan bahwa KAP harus menetapkan kebijakan dan prosedur yang dirancang untuk memberikan keyakinan memadai bahwa KAP dan personelnya telah mematuhi ketentuan etika profesi yang berlaku. Oleh karena itu, KAP harus memiliki sistem pengendalian mutu yang mencakup struktur organisasi, kebijakan dan prosedur yang ditetapkan KAP untuk memberikan keyakinan memadai tentang kesesuaian penugasan profesional (Pradana \& Biswan, 2018). Auditor dituntut untuk mengimplementasikan ketujuh unsur sistem pengendalian mutu dalam KAP berdasarkan pedoman SPM 1 dalam setiap penugasan perikatan audit yang dikerjakan untuk memberi keyakinan memadahi bahwa laporan hasil audit yang diterbitkan telah memenuhi standar audit dan ketentuan yang berlaku (Pradana \& Meiden 2016). Sistem pengendalian mutu merupakan prosedur yang diterapkan dalam KAP untuk mendukung kinerja para auditor agar sesuai dengan standar tanggungjawab yang diberikan (Nurrohmah, 2016).

Bandura (1986) menjelaskan bagaimana orang memperoleh dan mengelola atau menjaga pola-pola perilaku. Hal ini juga menyuguhkan dasar bagi adanya strategi intervensi dalam melakukan evaluasi terhadap perubahan perilaku bergantung pada faktor lingkungan, orang, dan perilaku (Laila, 2015). Keberhasilan penerapan sistem pengendalian mutu KAP dan penerapan etika profesi akuntan publik sebagai faktor lingkungan yang baik dalam diri seorang auditor dapat dilihat dari komitmen yang kuat dan dapat memberikan dampak positif dalam berperilaku ataupun hasil kerja yang maksimal bagi seorang akuntan profesional. Berdasarkan argumen tersebut dinyatakan hipotesis pertama sebagai berikut.

$\boldsymbol{H}_{1}$ : Terdapat hubungan positif antara sistem pengendalian mutu dengan etika profesi akuntan publik dalam menjalankan profesi sebagai seorang akuntan profesional.

\section{Hubungan Sistem Pengendalian Mutu dengan Skeptisisme Profesional Akuntan Publik}

Bandura (1986) telah memberi penekanan tentang bagaimana perilaku manusia dipengaruhi oleh lingkungan sekitar melalui peneguhan (reinforcement) dan pembelajaran peniruan (observational learning). Cara berfikir terhadap sesuatu yaitu bagaimana tingkah laku mempengaruhi lingkungan sekitar dan menghasilkan peneguhan (reinforcement) dan peluang untuk diperhatikan oleh orang lain (observational opportunity) (Ichsan \& Nugroho, 2014). Lingkungan dapat 
mempengaruhi seseorang dalam mengubah cara berpikir mereka dalam hal kinerja dari perilaku itu sendiri yang disebut sebagai interaksi antara lingkungan dengan perilaku. Perilaku seseorang dapat dipengaruhi oleh faktor eksternal. Demikian sebaliknya perilaku seseorang dapat mempengaruhi lingkungan dimana mereka berada (Pengkajian, 2016)

Dalam menjalankan tugasnya, para auditor perlu untuk memertimbangkan kemungkinan adanya kecurangan yang terjadi pada setiap tahapan kegiatan operasional di suatu entitas. Skeptisme profesional auditor perlu menjadi perhatian dalam melakukan pendeteksian kecurangan saat melaksanakan audit. Ningsih \& Nadirsyah (2017) mengatakan bahwa sikap skeptis yang baik mengarahkan para auditor untuk lebih waspada dan berhati-hati dalam mengumpulkan bukti audit sehingga hasil yang didapatkan lebih berkualitas. Fauji \& Sudarma (2015) mengatakan bahwa sistem pengendalian mutu dapat memberikan penilaian tinggi terhadap KAP karena dapat meningkatkan kepercayaan dari masyarakat terhadap kinerja KAP tersebut. IAPI (2013) mengatakan bahwa sistem pengendalian mutu memberikan pedoman untuk KAP dalam pelaksanaan pengendalian kualitas jasa atas hasil perikatan. Standar pengendalian mutu merupakan suatu proses yang dilakukan untuk memastikan bahwa suatu output dapat memenuhi tujuan dan spesifikasi yang telah ditetapkan sebelumnya yang diwujudkan dengan mengunakan pedoman atau standar yang telah ditetapkan (Nanda, 2019).

Setiap KAP memahami dan menerapkan prinsip-prinsip sistem pengendalian mutu serta mengarahkan para auditornya memiliki sikap skeptis yang tinggi dalam menjalankan tanggungjawabnya. Hal ini dapat mencegah terjadinya kesalahan dalam menyajikan laporan audit terhadap pihak-pihak yang berkepentingan. Berdasarkan argumen tersebut dinyatakan hipotesis kedua sebagai berikut.

$\boldsymbol{H}_{2}$ : Terdapat hubungan positif antara sistem pengendalian mutu dengan skeptisme profesional akuntan publik dalam menjalankan profesi sebagai seorang akuntan profesional.

\section{Hubungan Etika Profesi Akuntan Publik dengan Skeptisme Profesional Akuntan Publik}

Skeptisme profesional merupakan sikap yang dimiliki oleh seorang auditor dalam mengumpulkan bukti audit yang memiliki pikiran yang selalu mempertanyakan dan memberikan penilaian kritis atas bukti yang mencurigakan (Nandiati, 2018). Merici (2014) mengatakan bahwa skeptisme profesional sangat berpengaruh dalam ketepatan pemberian opini auditor. Hal ini menjadi salah satu hal yang dapat menunjang etika profesi akuntan publik yang harus dimiliki oleh seorang auditor dalam menjalankan profesinya sebagai seorang akuntan profesional.

Seorang auditor dalam menjalankan profesinya harus memahami setiap prinsip etika yang berlaku agar dapat mencegah terjadinya perilaku yang tidak etis dalam menjalankan tanggungjawabnya sebagai seorang akuntan profesional dan memiliki 
skeptisisme profesional tinggi agar dapat mendeteksi setiap kecurangan yang terjadi sehingga kualitas audit seorang auditor lebih mudah mendapatkan kepercayaan dari masyarakat serta dapat mencegah terjadinya kecurangan. Berdasarkan argumen tersebut dinyatakan hipotesis ketiga sebagai berikut.

$\boldsymbol{H}_{3}$ : Terdapat hubungan positif antara etika profesi dengan skeptisme profesional akuntan publik dalam menjalankan profesi sebagai seorang akuntan profesional.

\section{Model Penelitian}

Penelitian ini menggambarkan hubungan sistem pengendalian mutu KAP dengan etika profesi dan skeptisme profesional auditor. Berdasarkan hal tersebut maka model penelitian disusun sebagai berikut :

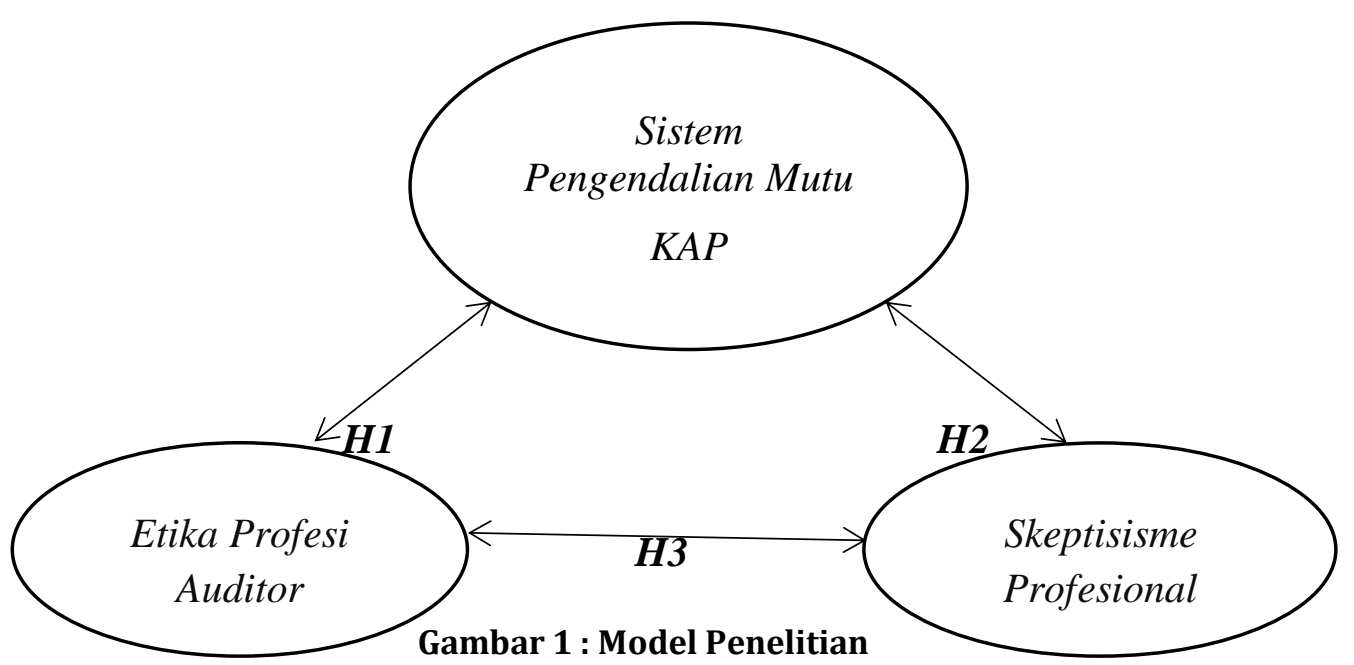

\section{Metoda}

Penelitian ini dilakukan dengan menggunakan metode deskriptif kuantitatif. Populasi penelitian adalah para auditor yang bekerja di KAP di Indonesia. Perolehan data dilakukan dengan menggunakan teknik penyempelan convinience sampling. Data penelitian diperoleh melalui penyebaran kuesioner. Kuesioner disebarkan secara online menggunakan google form yang dikirim melalui email dan media sosial.

Dalam penelitian ini menggunakan tiga variabel yaitu satu variabel yaitu sistem pengendalian mutu KAP, etika profesi auditor dan skeptisme profesional auditor. Sistem pengendalian mutu merupakan standar pokok dalam meningkatkan kepercayaan pengguna atas jasa yang disediakan oleh KAP ( Nanda, 2019). Sistem pengendalian mutu KAP diukur menggunakan lima skala Likert (skor 1 = sangat tidak setuju, skor 5 = sangat setuju). Skor 1 (sangat tidak setuju) mengindikasikan bahwa para responden sangat kurang memahami prinsip sistem pengendalian mutu KAP yang baik, sedangkan skor 5 (sangat setuju) mengindikasikan bahwa para responden 
sangat memahami sistem pengendalian mutu KAP yang baik. Indikator penelitian yang digunakan dalam penelitian ini diadopsi dari SPM 1 (2013), terdiri dari 7 (tujuh) indikator yaitu: (1) Tanggung jawab kepemimpinan KAP atas mutu, (2) Ketentuan etika profesi yang berlaku, (3) Penerimaan dan keberlanjutan hubungan dengan klien dan perikatan tertentu, (4) Sumber daya manusia, (5) Pelaksanaan perikatan, (6) Pemantauan dan (7) Dokumentasi.

Etika profesi auditor adalah nilai-nilai tingkah laku atau aturan-aturan tingkah laku yang diterima dan digunakan oleh organisasi profesi akuntan yang meliputi kepribadian, kecakapan profesional, tanggung jawab, pelaksanaan kode etik dan penafsiran dan penyempurnaan kode etik (Wahyuni, 2017). Etika mengikat kepada anggota profesi dan tidak boleh bertentangan dengan prinsip etika (Wibowo, 2014). Pengukuran konsep menggunakan skala Likert lima poin. Indikator penelitian yang digunakan dalam penelitian ini diadopsi dari penelitian Wahyuni (2017) terdiri dari kepribadian, kecakapan profesional, tanggung jawab, pelaksanaan kode etik, penafsiran dan penyempurnaan kode etik.

Skeptisme akuntan publik adalah sikap yang dimiliki oleh seorang auditor dalam mengumpulkan bukti audit dan selalu mempertanyakan dan mengevaluasi bukti yang didapatkan, dalam hal ini auditor dapat menggunakan keterampilan, kemampuan dan pengetahuan profesi auditor dalam melaksanakan tugasnya secara baik (Anggriani, 2015). Skeptisme profesional auditor diukur berdasarkan sikap skeptis yang tinggi dalam menemukan penyimpangan laporan keuangan, pengetahuan terhadap skeptisisme profesional akuntan publik, mempunyai sikap skeptis terhadap temuan audit yang berhubungan dengan wajar tidaknya laporan keuangan, bersikap cermat dan seksama dalam melaksanakan tugas akuntan publik merupakan faktor sikap. Skala pengukuran menggunakan skala Likert 5 poin. Indikator penelitian yang digunakan dalam penelitian ini diadopsi dari penelitian Hurt (2003) dalam (Alfiati, 2017) terdiri dari questioning mind (pola pikir yang selalu mempertanyakan), suspension of judgement (penundaan pengambilan keputusan), search of knowledge (mencari pengetahuan), impersonal understanding (pemahaman interpersonal), self confidence (percaya diri), self determination (keteguhan hati).

Analisis data merupakan proses pengujian, mengolah dan mengorganisasikan data secara sistematis dan rasional sesuai tujuan dari penelitian serta mendeskripsikan hasil data dari penelitian dengan menggunakan tabel sebagai alat bantu dalam menginterprestasikan. Keputusan valid tidaknya butir kuesioner ditentukan dengan membandingkan antara probabilitas hitung (sig.) koefisien korelasi (r) dan level of significance $(\alpha)$ Butir kuesioner dinyatakan valid apabila nilai probabilitas hitung lebih kecil dari level of significance (sig. $<\alpha$ ) (Nandiati, 2018). Selanjutnya pengujian reliabilitas kuesioner dilakukan dengan menggunakan koefisien alpha-cronbach dengan kriteria jika nilai alpha-cronbach lebih besar dari 0,6. Sebagai bagian dari uji data dilakukan uji linieritas untuk mengetahui apakah setiap variabel bebas memiliki pengaruh yang linier atau tidak terhadap variabel terikatnya (Basyari, 2013). Pengujian hipotesis menggunakan analisis bivariat dengan melakukan pengujian koefisien antara variabel bebas dengan variabel terikatnya (Basyari, 2013). 


\section{Hasil dan Pembahasan}

Berdasarkan hasil pengumpulan data melalui penyebaran kuesioner secara online melalui google form diperoleh 96 responden yang merupakan auditor dari KAP yang berlokasi di Makassar, Semarang, Surabaya, Samarinda, Balikpapan, Bogor, Jakarta, Tangerang, dan Surakarta. Adapun proses penyebaran kuesioner hingga terkumpul 96 kuesioner layak olah tergambar melalui tabel 1 berikut ini.

Tabel 1. Deskripsi Penyebaran Kuesioner

\begin{tabular}{ccc}
\hline Keterangan & Jumlah & Prosentase \\
\hline Kuesioner yang dikirim & 150 kuesioner & $100 \%$ \\
Kuesioner yang terkumpul & 110 kuesioner & $73,33 \%$ \\
Kuesioner yang tidak lengkap & 14 Kuesioner & $9,33 \%$ \\
Kuesioner yang lengkap dan diolah & 96 Kuesioner & $64 \%$ \\
\hline
\end{tabular}

Berdasarkan Tabel 1 di atas penyebaran kuesioner dilakukan secara online menggunakan google form dikirim ke 23 Kantor KAP yang berada di Indonesia. Kuesioner yang dikembalikan dan terisi sebanyak 110 kuesioner dari sembilan lokasi KAP, kuesioner yang tidak lengkap sebanyak 14 kuesioner dan kuesioner yang lengkap dan dapat diolah sebanyak 96 kuesioner. Berikut disajikan karakteristik responden yang diperoleh melalui penyebaran kuesioner.

Tabel 2. Karakteristik Responden

\begin{tabular}{cccc}
\hline Karakteristik & Keterangan & Jumlah & $\%$ \\
\hline Jenis Kelamin & Laki - laki & 59 & $61,5 \%$ \\
& Perempuan & 37 & $38,5 \%$ \\
Umur & Jumlah & 96 & $100 \%$ \\
& 20 sampai 30 Thn & 21 & $21,9 \%$ \\
& 31 sampai 40 Thn & 39 & $40,6 \%$ \\
& 41 sampai 50 thn & 26 & $27,1 \%$ \\
& Diatas 50 Tahun & 10 & $10,4 \%$ \\
Pendidikan terakhir & Jumlah & 96 & $100 \%$ \\
& Strata - 1 & 59 & $61,5 \%$ \\
& Strata - 2 & 32 & $33,3 \%$ \\
& Strata 3 & 5 & $5,2 \%$ \\
Masa kerja & Jumlah & 96 & $100 \%$ \\
& 1 sampai 3 Tahun & 20 & $20,8 \%$ \\
& 4 sampai 6 Tahun & 34 & $35.4 \%$ \\
& 7 sampai 10 Tahun & 18 & $18,8 \%$ \\
& Diatas 10 Tahun & 24 & $25,0 \%$ \\
& Jumlah & 96 & $100 \%$ \\
Jabatan & Magang & 15 & $15,6 \%$ \\
& Junior & 25 & $26,0 \%$ \\
& Senior & 30 & $31,3 \%$ \\
& Partner & 12 & $12,5 \%$ \\
& Manager & 14 & $14,6 \%$ \\
& & 96 & $100 \%$ \\
\hline
\end{tabular}

Berdasarkan data tabel 2 di atas responden dalam penelitian ini didominasi oleh pria $(61,5 \%)$ dengan usia 31 sampai 40 tahun $(40,6 \%)$. Jenjang pendidikan responden didominasi oleh lulusan strata $1(61,5 \%)$, masa kerja empat sampai enam tahun $(35,4 \%)$, dan jabatan senior auditor (31,3\%). Hasil pengujian validitas dan reliabilitas menunjukkan bahwa semua indikator konsep valid dan statistik cronbach's alpha dari 
ketiga variabel menunjukkan nilai lebih dari 0,6. Statistik cronbach's alpha sistem pengendalian mutu 0,955, etika profesional akuntansi 0,787, dan skeptisme profesional auditor 0,785 .

Berikut ini merupakan statistik deskriptif dari hasil penelitian tentang hubungan sistem pengendalian mutu dengan etika profesi Akuntan Publik dan skeptisisme profesional Akuntan Publik berdasarkan jabatan di dalam Kantor Akuntan Publik. Ikhtisar statistik deskriptif berdasarkan jabatan dalam dilihat pada Tabel 3.

Tabel 3. Statistik Deskriptif Berdasarkan Jabatan

\begin{tabular}{cccccc}
\hline \multirow{2}{*}{ Variabel } & \multicolumn{5}{c}{ Mean } \\
\cline { 2 - 6 } & Magang & Junior & Senior & Manager & Partner \\
\hline SPM & 116,40 & 119,32 & 120,40 & 121,00 & 123,50 \\
Etprof & 53,67 & 54,04 & 54,77 & 56,71 & 57,42 \\
Skeptis & 36,27 & 36,80 & 38,47 & 37,79 & 38,33 \\
\hline
\end{tabular}

Pengujian hipotesis dilakukan untuk mengetahui ada atau tidaknya hubungan antara variabel (Basyari, 2013). Hasil pengujian hipotesis menggunakan korelasi Perason ditunjukkan pada tabel 4 berikut ini.

Tabel 4. Ikthisar Pengujian Hipotesis

\begin{tabular}{cccc}
\hline & SPM-EPA & SPM-SPA & EPA-SPA \\
\hline Pearson Correlation & $0,598^{* *}$ & $0,765^{* *}$ & $0,642^{* *}$ \\
Sig. (2-tailed) & 0,000 & 0,000 & 0,000 \\
$\mathrm{R}^{2}$ & 0,351 & 0,580 & 0,405 \\
& $\mathrm{H} 1$ & $\mathrm{H} 2$ & $\mathrm{H} 3$ \\
Level of Significance $(\alpha)$ & $5 \%$ & & \\
\hline
\end{tabular}

Berdasarkan Tabel 4 dapat disimpulkan bahwa hasil pengujian hipotesis pertama menunjukkan nilai signifikansi sebesar 0,00 lebih kecil dari alpa 0,05 dan $r$ hitung sebesar 0,598 lebih besar dari t tabel sebesar 0,200. Hipotesis 1 didukung. Sistem pengendalian mutu berhubungan positif dengan etika profesi. Pengujian hipotesis kedua menunjukkan nilai signifikansi sebesar 0,00 lebih kecil dari alpa 0,05 dan $r$ hitung sebesar 0,765 lebih besar dari t tabel sebesar 0,200. Hipotesis kedua didukung. Sistem pengendalian mutu berhubungan positif dengan skeptisme profesional auditor. Pengujian hipotesis ketiga memperoleh hasil nilai signifikansi sebesar 0,00 lebih kecil dari alpa 0,05 dan $r$ hitung sebesar 0,642 lebih besar dari t tabel sebesar 0,200 . Hipotesis ketiga didukung. Etika profesi berhubungan positif dengan skeptisme profesional auditor.

Hipotesis pertama dalam penelitian ini menunjukkan adanya hubungan positif antara sistem pengendalian mutu dengan etika profesi auditor. Hasil analisis menggunakan korelasi product moment menunjukkan koefisien korelasi sebesar 0,598 dan harga koefisien determinasi sebesar 0,351. Hipotesis pertama menunjukkan adanya hubungan positif antara Sistem Pengendalian Mutu dengan etika profesi Akuntan Publik. Penerapan sistem pengendalian mutu KAP yang baik dan penerapan etika profesi oleh para akuntan publik berperan penting dalam memberikan hasil audit yang berkualitas dan memberikan manfaat yang akurat bagi pemakai jasa serta dapat 
meningkatkan kepercayaan publik. Akuntan publik dalam melaksanakan jasa profesionalnya sesuai dengan standar teknis profesional yang relevan. Dengan demikian dapat dikatakan bahwa semakin tinggi penerapan Sistem Pengendalian Mutu dalam KAP maka akan semakin tinggi penerapan etika profesi Akuntan Publik dalam menjalankan tugas sebagai seorang auditor yang profesional.

Berdasarkan Tabel 3 distirbusi frekuensi Sistem Pengendalian Mutu, dapat dilihat rata-rata tertinggi responden berdasarkan jabatan adalah pada tingkat partner sebesar 123,50 yang berarti berdasarkan tingkatan dalam Kantor Akuntan Publik pimpinan memiliki tanggung jawab yang lebih besar dalam penerapan Sistem Pengendalian Mutu yang baik untuk menciptakan lingkungan kerja yang baik bagi para anggotanya sehingga kinerja yang dihasilkan lebih maksimal dalam menghasilkan laporan audit yang berkualitas.

Hasil penelitian ini juga sejalan dengan hasil penelitian Anggraeni \& Badera (2013) mengatakan bahwa dalam sebuah KAP Sistem Pengendalian Mutu dioperasikan sebagai acuan bagi KAP dalam melaksanakan pengendalian atas kualitas jasa yang dihasilkan dengan mematuhi standar-standar yang telah ditetapkan oleh Dewan Standar Profesional Akuntan Publik Institut Akuntan Publik Indonesia (DSPAP IAPI) dan Aturan Etika Akuntan Publik yang diterbitkan oleh IAPI. Penelitian ini membuktikan bahwa adanya hubungan positif antara sistem pengendalian mutu KAP dengan etika profesi dalam menjalankan tugas sebagai akuntan profesional.

Hasil pengujian hipotesis kedua menggunakan korelasi product moment menunjukkan koefisien korelasi sebesar 0,765 dan harga koefisien determinasi sebesar 0,580 . Terdapat hubungan positif dan signifikan antara sistem pengendalian mutu dengan skeptisisme profesional auditor. Hipotesis kedua menunjukkan bahwa terdapat hubungan positif dan signifikan antara Sistem Pengendalian Mutu dengan skeptisisme profesional auditor. Penerapan sistem pengendalian mutu KAP yang baik maka lebih efektif dan berdampak positif bagi KAP dalam melaksanakan pengendalian kualitas jasa yang dihasilkan dan skeptisisme profesional auditor sudah cukup baik, sikap skeptis tinggi yang dimiliki para auditor cenderung lebih berhatihati dalam mendapatkan informasi atas bukti audit sehingga hasil yang didapatkan lebih berkualitas. Dengan peningkatan kewaspadaan auditor dalam mengevaluasi bukti audit, hal ini menunjukkan skeptisme profesional auditor yang didasari keraguan atau keingintahuan mengarah pada pembentukan kualitas atas hasil audit yang dihasilkan. Semakin paham seorang auditor terhadap sistem pengendalian mutu KAP maka semakin tinggi sikap skeptis yang dimiliki dalam membuktikan hasil audit.

Berdasarkan Tabel 3 distribusi frekuensi skeptisisme profesional, dapat dilihat ratarata tertinggi responden berdasarkan jabatan adalah pada tingkat senior sebesar 38,47 yang berarti bahwa dalam membuktikan keandalan laporan audit dibutuhkan pemahaman tingkat skeptis yang tinggi dengan menggunakan pengalaman, keterampilan, kemampuan dan pengetahuan profesi auditor yang dimiliki dalam mencari bukti audit dan tetap berhati - hati dalam pengambilan keputusan berdasarkan fakta yang ditemukan di lapangan. 
Hasil penelitian ini sejalan dengan penelitian Fauji \& Sudarma (2015) mengatakan bahwa sistem pengendalian mutu wajib diterapkan di dalam Kantor Akuntan Publik yang dapat mencakup unsur pengendalian mutu dengan implementasi secara efektif pada sistem tersebut. Ningsih \& Nadirsyah (2017) mengatakan bahwa sikap skeptis yang baik menunjukkan bahwa para auditor akan lebih waspada dan berhati-hati dalam mengumpulkan bukti audit sehingga hasil yang didapatkan lebih berkualitas.

Hasil pengujian hipotesis ketiga menggunakan korelasi product moment menunjukkan koefisien korelasi sebesar 0,642 dan harga koefisien determinasi sebesar 0,405 . Terdapat hubungan positif dan signifikan antara etika profesi akuntan publik dengan skeptisisme profesional akuntan publik. Hipotesis ketiga menunjukkan bahwa terdapat hubungan positif dan signifikan antara etika profesi akuntan publik dengan skeptisisme profesional auditor. Auditor dalam menjalankan profesinya memahami dan menerapkan aturan etika profesi yang tercantum dalam aturan etika akuntan publik dan setiap akuntan publik memiliki sikap skeptis yang tinggi sehingga dalam membuktikan hasil audit para akuntan publik lebih memiliki keyakinan atas bukti-bukti yang dikumpulkan dan memberikan manfaat yang lebih akurat terhadap pengguna jasa.

Sikap skeptis auditor yang rendah akan menimbulkan hal yang buruk dalam pendeteksian kecurangan baik yang nyata maupun berupa potensi. Dengan sikap skeptis tinggi yang dimiliki auditor diharapkan memberikan kontribusi kemahiran profesional dalam menjalankan profesi. Setiap auditor dalam mengambil suatu keputusan akan mempertimbangkan bukti-bukti dan informasi pendukung lainnya yang berkaitan dengan hasil pemeriksaan. Skeptisisme profesional auditor dalam audit mengacu pada sikap yang mencakup pikiran yang mempertanyakan dan penilaian kritis terhadap bukti audit dan merupakan dasar dari profesi ini. Semakin tinggi etika seorang auditor semakin tinggi sikap skeptis yang dimiliki dalam mencari dan melakukan pembuktian terhadap informasi yang diperoleh.

Berdasarkan Tabel 3 distribusi frekuensi etika profesi akuntan publik, dapat dilihat rata-rata tertinggi responden berdasarkan jabatan adalah pada tingkat partner sebesar 57,42. Hal ini menunjukkan bahwa pimpinan dalam KAP harus memiliki kepribadian yang dilandasi oleh sikap jujur, berani, bijaksana dan bertanggungjawab dalam menciptakan lingkungan pekerjaan yang baik. Pimpinan KAP dapat meningkatkan kinerja bawahannya dalam mengarahkan dan membimbing para anggotanya tetap berintegritas dalam menjalankan tugas profesinya dan memiliki komitmen yang kuat dalam menerapkan etika profesi yang baik dalam KAP.

Hasil penelitian ini sejalan dengan penelitian Merici (2014) dan Handayani \& Lely (2015) mengatakan bahwa dalam profesi sikap skeptisisme profesional lebih ditekankan berhubungan pada penilaian dan pengumpulan bukti audit, sehingga auditor dapat memperkirakan kemungkinan sesuatu yang terjadi, seperti bukti yang kurang lengkap dan menyesatkan. Primaraharjo dan Handoko (2011) mengatakan bahwa auditor dalam menjalankan profesinya harus memiliki etika untuk 
mendapatkan kepercayaan dari pengguna jasa agar dapat mendukung kelancaran pekerjaan yang dilakukan.

\section{Simpulan}

Berdasarkan hasil analisis data yang telah dilakukan, dapat ditarik kesimpulan bahwa sistem pengendalian mutu KAP berhubungan positif dengan etika profesi akuntan publik dan skeptisme profesional auditor. Di samping itu, etika profesi auditor juga berhubungan positif dengan skeptisme profesional auditor. Para auditor dapat menunjukkan hubungan yang positif dalam menjalankan profesi sebagai akuntan profesional. Dengan penerapan sistem pengendalian mutu KAP yang baik, Kantor Akuntan Publik dapat beroperasi secara efektif dan efisien. Di dalamnya para auditor dalam menjalankan tugasnya berlandaskan pada etika profesi auditor dan memiliki sikap skeptisme profesional yang tinggi yang berarti akan dengan mudah mendapat kepercayaan dari masyarakat dalam membuktikan hasil audit yang berkualitas. Hasil penelitian ini diharapkan menjadi referensi bagi Kantor Akuntan Publik dalam mendukung untuk meningkatkan kinerja dan menciptakan lingkungan pekerjaan yang baik bagi para auditor.

Pada praktiknya penelitian ini memiliki beberapa keterbatasan. Pertama, data penelitian ini diperoleh berdasarkan persepsi responden melalui kuesioner. Tidak menutup kemungkinan bahwa persepsi responden berbeda dengan keadaan yang sesungguhnya. Keterbatasan kedua, secara keseluruhan indikator pengukuran konsep sistem pengendalian mutu yang digunakan masih mengacu pada SPM tahun 2013. Dalam perkembangannya dimungkinkan masih ada indikator SPM yang belum sepenuhnya digunakan dalam pengambilan data.

Saran untuk pengelola KAP sesuai dengan hasil penelitian ini adalah dapat meningkatkan dan mempertahankan penerapan sistem pengendalian mutu yang baik dalam Kantor Akuntan Publik. Sistem pengendalian mutu yang baik akan menciptakan lingkungan kerja yang profesional. Kemudian bagi para auditor perlu meningkatkan pemahaman etika profesi dan mengasah sikap skeptis dalam menjalankan tugas sebagai akuntan profesional. Upaya yang berkesinambungan dari KAP maupun auditor akan mengarahkan pada perwujudan kualitas audit yang baik. Akhirnya isi yang dikaji dalam penelitian ini dapat diteliti kembali dengan penggunaan metode yang berbeda dan memperhatikan perkembangan peraturan terkait dengan SPM di KAP. 


\section{Daftar Pustaka}

Abdi, \& Harun. (2017). Hubungan Pemanfaatan Internet Sebagai Sumber Belajar Dengan Hasil Belajar Geografi Siswa Kelas X Lab School Banda Aceh. Jurnal Ilmiah Mahasiswa Pendidikan Geografi FKIP Unsyiah, 2(1), 78-91.

Alfiati. (2017). Pengaruh Etika Auditor, Skeptisisme Profesional Dan Kompetensi Auditor Terhadap Kualitas Audit. Jurnal Ilmiah Akuntansi Dan Bisnis, 2(1), 196-130.

Anggraeni, \& Badera. (2013). Pengaruh Penerapan Sistem Pengendalian Mutu Pada Kinerja Auditor Di Kantor Akuntan Publik Provinsi Bali. E-Jurnal Akuntansi Universitas Udayana, 5(2), 307-325.

Anggriani. (2015). Analisis Faktor-Faktor Yang Memengaruhi Skeptisisme Profesional Auditor. Jurnal Ilmiah Akuntansi Dan Bisnis, 19(2), 99-114.

Basyari. (2013). Hubungan Antara Minat Dan Prestasi Belajar Sejarah Dengan Kesadaran Sejarah Siswa MAN Yogyakarta III. Jurnal Ilmiah Mahasiswa Ekonomi Akuntansi, 8(1), 487-492.

Butar. (2017). Penerapan Skeptisisme Profesional Auditor Internal Pemerintah dalam Mendeteksi Kecurangan (Studi Kasus pada Auditor Perwakilan BPKP Provinsi Jawa $\begin{array}{lllll}\text { Tengah). Jurnal Ekonomi Dan } & \text { Bisnis, }\end{array}$ https://doi.org/10.24914/jeb.v20i1.1003

Damawati, \& Wahyuningsih. (2016). Pemahaman Mengendai Undang - Undang Dan Etika Profesi Akuntan Publik Terhadap Pemilihan Karier Sebagai Akuntan Publik. Jurnal Ilmiah Ekonomi Islam, 2(3), 172-182.

Darmawati, \& Puspitasari. (2018). Pengaruh Penerapan Sistem Pengendalian Mutu (SPM) terhadap Kemampuan Auditor Dalam Mendeteksi Kecurangan. Jurnal Akuntansi \& Manajemen, 4(1), 967-973.

Fauji, \& Sudarma. (2015). Penerapan Sistem Pengendalian Mutu dalam Meningkatkan Kualitas Audit. Jurnal Akuntansi Multiparadigma, 6(1), 1-17. https://doi.org/10.18202/jamal.2015.04.6005

Handayani, \& Lely. (2015). Pengaruh Independensi Auditor dan Kompetensi Auditor Pada Skeptisisme Profesional Auditor Dan Implikasinya Terhadap Kualitas Audit. E-Jurnal Akuntansi Universitas Udayana, 10(1), 229-243.

Herman. (2011). Pengaruh Penerapan Aturan Etika Terhadap Peningkatan Profesionalisme Akuntan Publik Pada Kantor Akuntan Publik Dipekanbaru. Jurnal Ekonomi Dan Ilmu Sosial Universitas Islam Negeri Sultan Syarif Kasim Riau, 10(2), 27-51.

Ichsan, \& Nugroho. (2014). Peranan Akuntan Dalam Mewujudkan Good Governance Pada Organisasi Sektor Publik Dan Pengaruhnya Terhadap Kinerja Organisasi. Jurnal Akuntansi Dan Auditing, 10(1), 64-74.

Juhara. (2017). Pengaruh Kode Etik Akuntan Publik Terhadap Kualitas Hasil Audit Pada Kantor Akuntan Publik Di Bandung. Jurnal Bisnis Dan Iptek, 10(2), 95-104.

Laila. (2015). Pemikiran Pendidikan Moral Albert Bandura. Jurnal Pendidikan Akuntansi Indonesia, 3(1), 50-89. 
Malik, Abdul. (2017). Mitra Ernst \& Young Indoinesia didenda Rp 13 Milliar di AS. WWW.tempo.co.id, 11/02/2017)

Maulita. (2015). Pengaruh Dukungan Rekan Kerja dan Etika Profesional Terhadap Kinerja Auditor Pada Kantor Akuntan Publik (KAP) Di Jakarta. Jurnal Akuntansi, 1(2), 6-17. https://doi.org/10.1145/3132847.3132886

Merici. (2014). Pengaruh Skeptisisme Profesional, Pengalaman Audit, Keahlian Audit, Independensi, Dan Kompetensi Terhadap Ketepatan Pemberian Opini Auditor Pada KAP Kota Malang. Jurnal Akuntansi \& Manajemen, 10(2), 1-13.

Mulyani, \& Munthe. (2018). Pengaruh Skeptisisme Profesional, Pengalaman Kerja, Audit Fee Dan Independensi Terhadap Kualitas Audit Pada KAP Di DKI Jakarta. Jurnal Akuntansi Trisakti, 5(2), 151-170. https://doi.org/10.25105/jat.v5i2.5229

Nandiati. (2018). Pengaruh Skeptisisme Dan Gender Terhadap Keputusan Auditor Dalam Situasi Konflik Audit. Jurnal Riset Akuntansi Dan Keuangan, 6(2), 12-25. https://doi.org/10.24036/wra.v6i2.102511

Naufa, \& Abdi. (2017). Hubungan Partisipasi Orang Tua Dan Motivasi Belajar Dengan Hasil Belajar Geografi Siswa kelas XII IPS SMA Negeri 12 Banda Aceh. Jurnal Ilmiah Mahasiswa Pendidikan Geografi FKIP Unsyiah, 2(3), 125-136.

Ningsih, \& Nadirsyah. (2017). Pengaruh Independensi, Skeptisisme Profesional Auditor, Penerapan Standar Audit, Dan Etika Audit Terhadap Kualitas Hasil Audit (Studi Pada Auditor BPK RI Perwakilan Provinsi Aceh). Jurnal Ilmiah Mahasiswa Ekonomi Akuntansi, 2(3), 48-58.

Nurrohmah. (2016). Pengaruh Sistem pengendalian Mutu Kantor Akuntan Publik Terhadap Efektivitas Perencanaan Audit. Jurnal Riset Akuntansi Dan Keuangan, 4(1), 974-983.

Pengkajian. (2016). Peranan Etika Profesi Dalam Perilaku Akuntan. Jurnal Akuntansi \& Manajemen, 15(1), 24-37.

Pradana \& Biswan. (2018). Penerapan Sistem Pengendalian Mutu Kantor Akuntan Publik Pada KAP Ashari, CPA. Jurnal Akuntansi Dan Auditing, 2(1), 39-58.

Pradana \& Meiden. (2016). Studi Dramaturgi: Implementasi Sistem Pengendalian Mutu Kantor Akuntan Publik. Jurnal Auditing, 5(2), 11-40.

Primaraharjo \& Handoko. (2011). Pengaruh Kode Etik Profesi Akuntan Publik Terhadap Kualits Audit Auditor Independensi di Surabaya. Jurnal Akuntansi Kontemporer, 3(1), 27-52.

Rustiana. (2016). Pengaruh Skeptisisme Profesional Auditor Terhadap Kemampuan Auditor Mendeteksi Kecurangan ( Studi Pada Badan Pemeriksa keuangan Perwakilan DIY ). Jurnal Akuntansi Dan Keuangan, 5(1), 1-15.

Sari \& Ratnadi. (2018). Pengaruh Skeptisisme Profesional, Etika, Tipe Kepribadian, Kompensasi, Dan Pengalaman Pada Pendeteksian Kecurangan. E-Jurnal Ekonomi Dan Bisnis Universitas $\quad$ Udayana, 29-56. https://doi.org/10.24843/eeb.2018.v07.i01.p02

Sukanti. (2012). Pengaruh Sertifikasi Guru Dan Motivasi Kerja Guru Terhadap Kinerja Guru SMA Negeri 1 Sentolo Kabupaten Kulon Progo Tahun 2012. Jurnal Pendidikan Akuntansi Indonesia, 10(1), 98-113. https://doi.org/10.21831/jpai.v10i1.924 
Wahyuni. (2017). Pengaruh Independensi, Etika Profesi Dan Integritas Auditor Terhadap Kualitas Audit Di Kantor Akuntan Publik Wilayah Daerah Istimewa Yogyakarta. Jurnal Ilmiah Mahasiswa Ekonomi Akuntansi, 5(1), 1-8.

Wibowo. (2014). Pengaruh Kode Etik Akuntan, Personal Ethical Philosophy, Corporate Ethical Value Terhadap Persepsi Etis Dan Pertimbangan Etis Auditor ( Studi Empiris pada Kantor Akuntan Publik di Jakarta ). Jurnal Ilmiah Akuntansi Dan Bisnis, 3(1), 1-19.

Wijayanto. (2014). Pengaruh Tekanan Anggaran Waktu, Kepatuhan Pada Kode Etik Dan Pengendalian Mutu Kantor Akuntan Publik (KAP) Terhadap Kualitas Audit. Jurnal Akuntansi Multiparadigma, 8(33), 44-96.

Wirakusuma, \& Sari. (2018). Pengaruh Skeptisisme Profesional, Etika, Tipe Kepribadian, Kompensasi, Dan Pengalaman Pada Pendeteksian Kecurangan. E-Jurnal Ekonomi Dan $\begin{array}{llll}\text { Bisnis Universitas } \quad \text { Udayana, } & \end{array}$ https://doi.org/10.24843/eeb.2018.v07.i01.p02

\section{Lampiran}

\section{Daftar Kuesioner}

\section{Pertanyaan}

\begin{tabular}{lllll} 
STS & TS & KS & S & SS \\
\hline
\end{tabular}

KAP tempat saya bekerja mempunyai kebijakan yang mengatur independensi auditor.

Semua personel di KAP tempat saya bekerja harus mematuhi ketentuan independensi sebagaimana diatur oleh Ikatan Akuntan Indonesia

KAP tempat saya bekerja melakukan evaluasi independensi auditor

KAP tempat saya bekerja menerapkan kebijakan yang mengatur masalah penugasan personel

KAP tempat saya bekerja menetapkan personel yang tepat pada setiap penugasan

Sebagai seorang akuntan pubilk, auditor bertanggung jawab terhadap profesi yang telah dipilih

Dalam pekerjaan, auditor akan mementingkan kepentingan umum

Dalam pekerjaan, auditor akan mementingkan kepentingan pribadi

Dalam pekerjaan, auditor bekerja sebagai satu kesatuan dengan rekan kerja

Prinsip kehati-hatian dalam bekerja selalu diterapkan saat bekerja.

Auditor memiliki kemampuan dalam mendeteksi kecurangan 
Auditor memberikan pertanyaan untuk pembuktian suatu objek tertentu kepada auditor yang lain.

Auditor tidak terburu - buru dalam pengambilan keputusan

Seorang auditor harus bersikap professional dalam memberikan keputusan terhadap hasil pemeriksaan.

Seorang auditor melakukan tahap-tahap pemeriksaan laporan keuangan sesuai standar teknis yang telah ditetapkan

Dalam melakukan penugasan pemeriksaan KAP tempat saya bekerja selalu mempertimbangkan aspek kerja sama tim

KAP tempat saya bekerja memiliki kebijakan yang mengatur masalah konsultasi

Auditor tidak akan membuat keputusan jika informasi belum valid

Auditor berusaha mencari informasi yang baru

Seorang auditor bekerja sesuai kode etik yang telah ditetapkan saat memeriksa laporan keuangan

Seorang auditor akan menggunakan kode etik hanya yang sesuai dengan keinginannya

KAP tempat saya bekerja menyediakan pedoman mengenai industri khusus yang dapat digunakan sebagai acuan dalam penugasan

Dalam KAP tempat saya bekerja ada staf yang ditunjuk untuk bertanggung jawab dalam memberikan konsultasi selama penugasan

Ada evaluasi secara berkala terhadap kebijakan konsultasi di KAP tempat saya bekerja

Auditor mempertimbangkan penjelasan dari orang lain

Auditor berusaha memecahkan informasi yang tidak konsisten

Auditor tidak akan secara langsung menerima pernyataan dari orang lain

Seorang auditor akan memegang teguh kode etik profesi walaupun mendapat kompensasi yang kecil

KAP tempat saya bekerja melaksanakan program pelatihan dalam bidang auditing bagi para personel secara berkala 
KAP tempat saya bekerja menyediakan informasi bagi personel mengenai perkembangan terkini dalam standar professional

Seorang auditor menafsirkan kode etik profesi sesuai keinginan pribadi

KAP tempat saya bekerja menyediakan informasi bagi personel mengenai prosedur teknis KAP

KAP tempat saya bekerja memiliki program untuk mengembangkan keahlian dalam bidang industri khusus

KAP tempat saya bekerja melaksanakan pelatihan ditempat kerja (on the-job training) selama pelaksanaan perikatan

Dalam KAP tempat saya bekerja ada kebijakan yang mengatur masalah promosi

Auditor tidak akan secara langsung membenarkan pernyataan dari orang lain

KAP tempat saya bekerja memiliki ketentuan kualifikasi yang harus dipenuhi berbagai tingkatan tanggung jawab professional

KAP tempat saya bekerja memiliki evaluasi kinerja personel

Seorang auditor bekerja dengan baik bahkan bersikap lebih dari ketentuan yang terdapat dalam kode etik

KAP tempat saya bekerja melakukan survey sebelum menerima penugasan dari klien baru

KAP tempat saya bekerja menetapkan prosedur calon klien

KAP tempat saya bekerja melakukan evaluasi kepada calon klien

KAP tempat saya bekerja membuat persetujuan mereka menjadi klien

KAP tempat saya bekerja adanya pertimbangan kemampuan pemeriksa untuk menyelesaikan penugasan ditinjau dari segi kompetensi

KAP tempat saya bekerja memiliki pertimbangan kemampuan pemeriksa untuk menyelesaikan penugasan ditinjau dari kemungkinan risiko pemeriksaan yang timbul

KAP tempat saya bekerja melakukan komunikasi dengan auditor terdahulu sebelum melakukan pemeriksaan dengan klien 
Seorang auditor tidak pernah menafsirkan kode etik sesuai keinginan pribadi

KAP tempat saya memiliki prosedur inspeksi bekerja yang diperlukan untuk memberikan keyakinan memadai bahwa kebijakan pengendalian mutu diterapkan secara efektif

KAP tempat saya bekerja melakukan evaluasi terhadap prosedur pengendalian mutu KAP

KAP tempat saya bekerja menerapkan uji kepatuhan personel terhadap prosedur pengendalian mutu

KAP tempat saya bekerja melakukan tindak lanjut terhadap temuan-temuan yang di dapat dari peninjauan pelaksanaan prosedur pengendalian mutu 